\title{
ARTYKUŁY
}

Klio. Czasopismo poświęcone dziejom Polski i powszechnym

PL ISSN 1643-8191, t. 60 (4)/2021, s. 173-210

(c) $(1) \Theta$

http://dx.doi.org/10.12775/KLIO.2021.040

Pawee Fiktus*

\section{Charter 77 in the journalism of the Parisian "Kultura"}

\section{Karta 77 w publicystyce paryskiej Kultury}

Streszczenie: Artykuł odnosi się do zagadnienia, w jaki sposób publicystyka paryskiej „Kultury” postrzegała rodzącą się w Czechosłowacji opozycję skupioną wokół Václava Havla. Mimo iż problematyka czechosłowacka nie była przedmiotem szczególnego zainteresowania ze strony Jerzego Giedroycia, to środowisko Karty 77 zostało dostrzeżone przez Redakcję „Kultury”, bacznie śledzącej jej działalność.

Słowa kluczowe: Insytut Literacki, Jerzy Giedroyc, „Kultura”, Karta 77, Václav Havel, czeska i słowacka emigracja, Jiř́ Lederer, Alexander Tomský

\begin{abstract}
Although the Czechoslovak theme was not of particular interest in the journalism of "Kultura" (compared to Ukrainian or Lithuanian issues), it covered issues concerning Poland's southern neighbour. The year 1968 marked a special period of increased interest in Czechoslovakia and the associated process of a series of social, political and economic reforms, which went down in history under the name of the Prague Spring. The period after the invasion by the Warsaw Pact troops and the start of the so-called process of normalization was also closely commented on by columnists and analysts of "Kultura". However, particular attention was paid to the activities of the opposition in the area of
\end{abstract}

* Wyższa Szkoła Prawa we Wrockawiu, ul. św. Jadwigi 12, 50-266 Wrocław, pawel. fiktus@prawowroclaw.edu.pl, ORCID: 0000-0002-2937-6859. 
Charter 77. The purpose of this article is to show how the Parisian "Kultura" referred to the opposition movement in Czechoslovakia. Moreover, Czechoslovak writers associated with Czechoslovak immigrant communities spoke out more often in "Kultura" pages.

Keywords: The Literary Institute, Jerzy Giedroyc, "Kultura”, Chart 77, Václav Havel, Czech and Slovak emigration, Jiří Lederer, Alexander Tomský

\title{
The Literary Institute in Maisons-Laffitte and the monthly "Kultura" - characteristics
}

\begin{abstract}
Thepre he Literary Institute was founded in Rome in 1946, and from 1947 it operated in Maisons-Laffitte, a suburb of Paris. The initiators of its creation were Polish intellectuals who during the Second World War fought in the ranks of the Polish Armed Forces associated with the Polish government residing in exile in London and who, for fear of the repressive activities of the Polish communist authorities, decided to remain in exile. The team included Jerzy Giedroyc ${ }^{1}$ (main editor), Henryk Giedroyc, ${ }^{2}$ Zofia Hertz, ${ }^{3}$
\end{abstract}

1 Jerzy Giedroyc (born on July 27, 1906 in Minsk - died on September 14, 2000 in Maisons-Laffitte). Before the war, he studied law and history at the University of Warsaw. He published Bunt Młodych (Youth Rebellion), which was transformed into the weekly "Polityka" in 1937. Before the war, he also worked at the Ministry of Agriculture and the Ministry of Industry. In September 1939, he was evacuated to Romania. He fought in the $2^{\text {nd }}$ Polish Corps. In 1946, together with Zofia Hertz, her husband Zygmunt Hertz and Józef Czapski, he founded the Literary Institute, which in 1947 moved to Maisons-Laffitte.

2 Henryk Giedroyc (born on January 12, 1922 in Warsaw - died on March 21, 2010 in Maisons-Laffitte), brother of Jerzy Giedroyc. During the Second World War, he served in the Carpathian Rifle Brigade, which was part of the $2^{\text {nd }}$ Polish Corps. After the war, he remained in exile. From 1952 he was associated with the Literary Institute in Maisons-Laffitte. In the years 2003-2010 he became the head of the Literary Institute and the president of the Kultura Literary Institute Association.

3 Zofia Hertz (de domo Neuding) (born on February 27, 1910 in Warsaw - died on June 20, 2003 in Maisons-Laffitte). A graduate of law studies at the University of Warsaw. In 1933, she was the first woman in Lodz to pass the notary exam, and then worked as a notary clerk. During the Second World War, she was arrested by the NKVD and exiled to the Mari ASSR. Together with the $2^{\text {nd }}$ Polish Corps, she made her way to Italy. In 1946, together with her husband Zygmunt Hertz (they got married in 1939), Jerzy Giedroyc and Józef Czapski, she founded the Literary Institute, which in 1947 was 


\section{Zygmunt Hertz, ${ }^{4}$ Gustaw Herling-Grudziński, ${ }^{5}$ Józef Czapski ${ }^{6}$ and the later Polish Nobel laureate Czesław Miłosz. ${ }^{7}$ It is worth adding that the founders}

moved to Maisons-Laffitte. After Jerzy Giedroyc's death, she headed the research work of the Literary Institute.

4 Zygmunt Hertz (born on January 18, 1908 in Warsaw - died on October 5, 1979 in Maisons-Laffitte). Before the Second World War, he worked in his father's trading company and gained the title of artillery officer (second lieutenant). During the war, he was arrested by the NKVD and, together with his wife, Zofia Hertz, deported to the Mari ASSR. Then he served in the $2^{\text {nd }}$ Polish Corps, with which he reached Italy. In 1946, together with his wife Zofia Hertz (they got married in 1939), Jerzy Giedroyc and Józef Czapski, he founded the Literary Institute, which in 1947 was moved to Maisons-Laffitte.

5 Gustaw Herling-Grudziński (born on May 20, 1919 in Kielce - died on July 4, 2000 in Naples) - before the Second World War, he studied Polish at the University of Warsaw. During the Second World War, he was active in the underground movement. He was arrested by the NKVD in 1940, then sentenced to 5 years' imprisonment and sent to Soviet labor camps. He was released in 1942 under the Sikorski-Majski Agreement. In the book $A$ world apart, he presented the reality of the camp. After the war, he remained in exile, cooperating with the Literary Institute in Maisons-Laffitte, Wiadomości published in London and Radio Free Europe. Like most Polish artists working in exile, in the era of the People's Republic of Poland, his works were forbidden to print and were published in underground publishing houses.

6 Józef Czapski (born on April 3, 1896 in Prague - died on January 12, 1993 in Maisons-Laffitte; proper name Hutten-Czapski). He studied law in St. Petersburg, painting at the Academy of Fine Arts in Warsaw and the Academy of Fine Arts in Kraków. He was a participant of the Polish-Bolshevik war and the September campaign in 1939. Then he fought in the $2^{\text {nd }}$ Polish Corps, with which he reached Italy. After the war, he remained in exile. Until his death, he collaborated with the Literary Institute in Maison-Laffitte. His works were often exhibited in Western European galleries. He was an author of numerous works on art, especially painting.

7 Czesław Miłosz (born on June 30, 1911 in Šeteniai (present-day Lithuania) - died on August 14, 2004 in Krakow). Before the Second World War, he studied law and Polish at the Stefan Batory University in Vilnius. Then he made his debut as a poet. During the war, he stayed in Poland together with his brother Andrzej Miłosz, helping in the hiding of Jews. After the Second World War, he worked in diplomacy in the United States and Paris. In 1951, he applied for political asylum in France. It was then that he established cooperation with the Literary Institute in Maisons-Laffitte. From 1960, he lived in the United States, giving lectures in Polish philology at Harvard and Berkeley. In 1980, he was awarded the Nobel Prize in the field of literature. In 1993, he moved permanently to Kraków. 
as well as the main activists of the Institute, before the Second World War, published in the form of a political journal called "Bunt Młodych" (from 1931), renamed "Polityka" in $1937 .{ }^{8}$

The main activity of the Literary Institute focused on publishing books and publications that could not appear in communist Poland for political reasons. It is also worth noting the very extensive correspondence of Jerzy Giedroyc with leading Polish intellectuals, which is now systematically published and made available to a wider group of readers. ${ }^{9}$ However, the most well-known form of the Institute's publishing activity was the monthly "Kultura" and the quarterly "Zeszyty Historyczne". ${ }^{10}$ Particular attention should be paid to the monthly "Kultura", which appeared until the death of Jerzy Giedroyc (14.09.2000). ${ }^{11}$ Literary works as well as texts, analyzes and political commentaries appeared in the pages of "Kultura". ${ }^{12}$ Separate account should be taken of political journalism, in which the issue of the policy of eastern Poland is of great importance. ${ }^{13}$ Moreover, in the pages of

8 R. Habielski, Dokad nam iść wypada?, Warszawa 2007; Zamiary, przestrogi, nadzieje: wybór publicystyki: „Bunt Młodych”, „Polityka” 1931-1939, eds. R. Habielski, J. Jaruzelski, Lublin 2008.

9 J. Giedroyc's correspondence with, among others, W. Gombrowicz, K. Jeleński, A. Bobkowski, J. Stempowski, Cz. Miłosz, L. Kołakowski, J. J. Lipski, J. Nowak-Jeziorański, Z. Najder, A. Janty-Połczyński, S. Kisielewski, Z. Siemaszko or Cz. Straszewicz, has been published.

10 „Zeszyty Historyczne” z perspektywy półwiecza, eds. R. Stobiecki, S. Nowinowski, Warszawa 2007.

11 The last issue appeared in September 2000 and was edited by Z. Hertz and H. Giedroyc (brother of Jerzy).

12 Recently, the following volumes have appeared including the selection of journalism published in "Kultura”: (Wizja Polski na łamach „Kultury” 1947-1976, vol. 1-2, ed. G. Pomian, Lublin 1999,; Realiści z wyobraźnia. Antologia „Kultury” 1976-2000, vol. 1-2, eds. B. Kerski, A. Kowalczyk, Lublin 2007.

13 Jerzy Giedroyc and Juliusz Mieroszewski (associate of the Institute) developed the concept of the so-called ULB (Ukraine-Lithuania-Belarus), according to which, after the fall of communism, Poland was to recognize the independence of these three states. Moreover, they were subjected to harsh criticism from other emigre circles as Poland was to recognize the Yalta order regarding the Polish eastern border, which, as a consequence, meant leaving former Polish lands within the borders of these three countries (together 
"Kultura", the texts were presented by publicists and writers from Central and Eastern Europe who were politically dependent on the USSR, such as the Ukrainian Bohdan Osadczuk, ${ }^{14}$ the Russian Mikhail Heller, ${ }^{15}$ Czechoslovaks Jiř́ Lederer ${ }^{16}$ and Alexander Tomský, ${ }^{17}$ Karel Kosík, ${ }^{18}$ Hanna Jechová ${ }^{19}$

with cities such as Vilnius, Grodno or Lviv), see e.g. J. Mieroszewski, Listy z Wyspy. ABC polityki „Kultury”, Warszawa 2012; A. Friszke, Życie polityczne emigracji, Warszawa 1999; P. Kowal, Testament Prometeusza, Wrocław 2018; A. Kowalczyk, Wena do polityki. O Giedroyciu i Mieroszewskim, vol. 1-2, Warszawa 2014.

14 Bohdan Osadczuk (born on August 1, 1920 in Kolomyia - died on October 19, 2011 in Czechówka). During the Second World War, he studied at the Humboldt University in Berlin. He obtained his PhD degree at the Free Ukrainian University. After the war, he also worked as a correspondent and commentator for German magazines. He was a long-time collaborator of the Literary Institute in Maisons-Laffitte and the author of numerous texts on Ukrainian matters published in "Kultura".

15 Mikhail Heller (born on August 31, 1922 in Mogilev - died on January 3, 1997 in Paris). He graduated from the Lomonosov University in Moscow in the field of history. He was sentenced to a labor camp. From 1957, he collaborated with the Polish Press Agency. From 1960 he lectured at the Sorbonne. He was a long-time collaborator.

16 Jiř́ Lederer (born on July 15, 1922 in Kvasiny - died on October 12, 1983 in Munich) - Czech writer and literary critic, author of numerous works devoted to Poland. In the 1970s, he was imprisoned for cooperation with the Czechoslovak opposition. After 1980, he lived in exile. His works were also published in "Kultura" issued by the Literary Institute in Maisons-Laffitte. In 1986, the editorial office of "Kultura" announced the establishment of the Jiří Lederer Award. Its first laureate was Andrzej Jagodziński - a leading translator of Czech and Slovak literature.

17 Alexander Tomský (born on December 13, 1947 in Frýdlant) - Czech political scientist and writer. After 1968 he went into exile, from which he returned in 1989. He is an author of numerous political commentaries published in Czechoslovak emigration circles.

18 Karel Kosík (born on June 26, 1926 in Prague - died on February 21, 2003 in Prague) studied at the Charles University in Prague and at the universities in Leningrad and Moscow. During the Second World War, he was active in the Czechoslovak resistance movement. He studied the thought of Karl Marx and was involved in the political changes in Czechoslovakia in 1968. In 1970, during the reign of Gustav Husák, he was dismissed from his job at the university. He returned to professional activity only after the so-called Velvet Revolution.

19 Hanna Jechová (born April 19, 1927 in Humpolec) - a researcher and translator of Polish and French literature. From 1976, she lectured at the University of Paris. 
or Pavel Hanus. ${ }^{20}$ With the appearance of Alexander Dubček ${ }^{21}$ on the political scene, a lot of space was devoted to the changes taking place in Czechoslovakia as part of the introduction of the so-called "socialism with a human face". However, when in August 1968, the Warsaw Pact armies entered Czechoslovakia, the Literary Institute published a special issue of "Kultura", containing sharp criticism of the communist authorities invading Poland's southern neighbor. It is worth adding that the Polish communist authorities fought against the activities of the Institute, not only prohibiting the distribution of its publications in Poland, ${ }^{22}$ but also vilifying it publicly. ${ }^{23}$

The entry of the Warsaw Pact troops into Czechoslovakia in 1968, as well as the subsequent takeover of power by Gustáv Husák, ${ }^{24}$ initiated

20 Pavel Hanus (born on June 8, 1928 in Prague - died on February 8, 1991 in Prague). He studied journalism in Prague. After the Second World War, he became known as the author of poems and literary texts. After the intervention of the Warsaw Pact troops in 1968, he also published in the Czechoslovakian Samizdat.

21 Alexander Dubček (born on November 7, 1921 in Uhrovec - died on November 7, 1992 in Prague). Before the Second World War, he was active in the Communist Party of Slovakia. He participated in the Slovak National Uprising. After the war, he actively participated in the communist movement. In 1968, he became the First Secretary of the Central Committee of the Communist Party of Czechoslovakia. The period of his rule was connected with the implementation of a number of economic and social reforms, interrupted by the intervention of the Warsaw Pact troops on August 21, 1968. In 1969 he was removed from the position of the First Secretary of the Central Committee of the Communist Party of Czechoslovakia. Then he worked in the diplomacy of the CSSR and from 1970 as a mechanizer. In 1989, during the so-called Velvet Revolution, he returned to political activity.

22 A special book of "Kultura" devoted to the issue of events in Czechoslovakia of 1968 appeared in the Polish language and separately in the Czech language. One could expect imprisonment for carrying the Institute's publications. For example, one of the smugglers' routes led through the Czechoslovak Tatra Mountains - see B. Kaliski, Kurierzy wolnego stowa: (Paryż-Praga-Warszawa 1968-1970), Warszawa 2014.

23 It should be added that after the fall of communism in Poland, readers were reminded of the most malicious texts concerning the Institute's activity in a collective volume Anty-Kultura, ed. M. Zieliński, Warszawa 1992.

24 Gustáv Husák (born on January 10, 1913 in Dubravka - died on November 18, 1991 in Bratislava). Before the outbreak of the Second World War, he was active in the 
a series of repressions against the opposition. "Kultura" published by the Literary Institute on a daily basis followed the process of limiting political freedom in the CSSR, as well as numerous harassments, persecutions, and the emergence of opposition circles around Charter 77. The aim of this paper is to show the way in which one of the most important figures of the then opposition that is Václav Havel ${ }^{25}$ and the functioning of Charter 77 were presented.

\section{Charter 77}

Two points are raised in the literature about the circumstances that influenced the creation of Charter 77. The underground bands DG 307 and The Plastic People of the Universe are mentioned first. Their presence on the

Czechoslovak communist movement. After the war, he was active in the Czechoslovak Communist Party and the Communist Party of Slovakia. In 1951 he was accused of "Slovak bourgeois nationalism". In 1954 he was sentenced to life imprisonment. In 1960, as a result of an amnesty, he regained his freedom, and in 1963 he was rehabilitated and returned to the party. When in 1968 Alexander Dubček became the First Secretary of the Central Committee of the Communist Party of Czechoslovakia, Gustáv Husák became his associate, taking the position of deputy prime minister of the CSSR. He was critical about the reform program after the intervention of the Warsaw Pact troops in August 1968. From 1969, he was the First Secretary of the Central Committee of the Communist Party of Czechoslovakia, and from 1975 the president of the CSSR. His policy was related to the so-called standardization process, consisting in departing from the most important reforms of 1968. On December 10, 1989, as a result of the so-called Velvet Revolution, as the president of the CSSR, he stepped down from office, and on January 18, 1990, he was expelled from the Communist Party.

25 Václav Havel (born on October 5, 1936 in Prague - died on December 18, 2011 in Hrádeček) came from a well-known Czech family of entrepreneurs and intellectuals. $\mathrm{He}$ was an author of numerous essays and theater plays repeatedly staged in numerous theaters. In the 1970s, he was a leading figure of the Czechoslovak opposition. As a result of the repression of the music group The Plastic People of the Universe by the Czechoslovak communist authorities, Charter 77 was created to protect fundamental human rights. In the 70s and 80s he was imprisoned many times. He was an active participant in the Velvet Revolution in 1989. In the years 1989-1992, he held the position of the president of Czechoslovakia, and, in 1993-2003, the President of the Czech Republic. 
Czechoslovak music scene was not accepted by the communist authorities at the time, who, using all means available to them, tried to limit their activities. Another point concerned the Helsinki Conference in 1975, during which communist states committed to respecting human rights. Although it was a declaration on paper while in practice human rights were still violated, opposition circles received a very important legal instrument in the fight against the communist regime.

The move away from the reforms introduced in Czechoslovakia during the so-called Prague Spring in 1968 and the process of so-called normalization performed by the then First Secretary of the Communist Party Gustáv Husák meant increasing interference with human rights and freedoms. Depriving people involved in the process of change in 1968 of work, suppressing opposition and civic initiatives critical of change after 1968 became a trademark of communist rule at the time. The Charter 77 document was created in December 1976 and was signed by 242 signatories on 1 January 1977. The initiators of this document include Václav Havel (playwright and writer), Jiř́ Hájk (Minister of Foreign Affairs in 1968) and Jan Patočka (Czechoslovak philosopher), who also served as the first spokesmen (representatives). The document accused the communist authorities of failing to comply with laws on human rights and freedoms - including religious freedom, freedom of expression or the right to privacy. The Czechoslovak communist authorities were called upon to build a dialogue with the public and to respect the agreements to which they had committed in writing. In addition, the Committee for the Defence of the Unjustly Persecute (VONS) was created parallel to Charter 77. This initiative, related to the creation of Charter 77, enjoyed an enthusiastic reception in democratic countries. The Czechoslovak Communist authorities, on the other hand, responded with repression and harassment against the signatories of the document. An example is the brutal interrogation of Jan Patočka, as a result of which he died. In addition to the forceful attempt to deal with the signatories of Charter 77, the Czechoslovak authorities drew up the so-called Anti-Charter, which was signed by Karel Gott, for example. The message of Charter 77 and its importance in the eastern block cannot be described in a few sentences, although it should be modestly added that it was one of the most important opposition initiatives in the era of the fight 
against communism, which had a very large impact on opposition circles in other countries. ${ }^{26}$

\section{Comments on Václav Havel and Charter 77 published in the 1970s}

For example, before the creation of Charter 77, the memorial of Václav Havel by Józef Lewandowski ${ }^{27}$ was summarized in the pages of "Kultura." 28 . The publicist of "Kultura" pointed out that in the CSSR, there was increased activity in the writing of memorials, letters, etc. addressed to Gustáv Husák, which, for fear of being reprinted in the foreign press, were becoming more and more troublesome. In the opinion of J. Lewandowski, "the Havel memorial has a different character. The subject of interest in it are not only the system problems, but the system itself, its regularities." ${ }^{29} \mathrm{He}$ pointed out that the phrase "hidden mechanisms" was used in the memorial, which in the opinion of J. Lewandowski means "[...] phenomena hidden from the public but expressive, or at least visible to the participants of the political game." ${ }^{30}$ Indeed, Havel mentioned the apparent "successes" of the government, such as discipline at work, participation in elections, activity in

26 A. Kaczorowski, Havel. Siła bezsilnych, Wołowiec 2014; idem, Praski elementarz (chapter: Lekcja Havla), Wołowiec 2012, pp. 177-204; P. Jokeš, Przewodnik po historii narodu i państwa, Kraków 2020, pp. 380-381; A. Szczepańska, Karta 77 w opinii dyplomacji PRL, in: Opozycja antykomunistyczna w krajach bloku wschodniego w latach 1945-1989, eds. M. Świder, K. Łabędź, Kraków 2014, pp. 263-277; Tylko krótko, proszę: interview with Karel Hvíždala, notes, documents / Václav Havel, Kraków 2007; Siła bezsilnych i inne eseje / Václav Havel, selection of texts made by A. S. Jagodziński [preface A. Michnik], Warszawa 2011; Zaoczne przestuchanie / Václav Havel, talks with K. Hvíždala; intro. S. Sierakowski, transl. J. Illg, Warszawa 2014.

27 Józef Lewandowski (born on August 15, 1923 in Konin - died on November 17, 2007 in Stockholm), a graduate of history studies at the University of Warsaw. From 1969 he worked in Stockholm and Uppsala. The author of works mainly from the Polish interwar period.

28 J. Lewandowski, Memoriat Václava Havela, "Kultura" 1975, vol. 12, pp. 80-88.

29 Ibidem, p. 81.

30 Ibidem. 
meetings or demonstrations. However, this was "superficial consolidation" because, according to Havel, society was plunging into an ever-greater crisis. In addition, "consolidation" should be treated as a reference to low instincts, such as fear. ${ }^{31}$

Another element that occurred in Czechoslovak society, as a result of Husák's rule, was "indifference" manifested by greater interest in private matters than state interests. ${ }^{32}$ In addition, Havel pointed to the collapse of culture, appropriated by the communist authorities. ${ }^{33}$

J. Lewandowski pointed out that the term "entropy" was used in the Václav Havel memorial, which means "the phenomenon of energy degradation". In addition, the Czechoslovak playwright raised issues related to the history of societies subjected to entropic regimes. ${ }^{34}$

Commenting on the Havel memorial, the "Kultura" publicist decided that the theses contained in it could be boldly applied in any totalitarian system. ${ }^{35} \mathrm{~J}$. Lewandowski, summarizing Havel's speech, recognizing that "[...] Havel's concept is a summary and giving shape to discussions among Czech intellectual opposition. At least this opinion is shared by the security authorities who, almost immediately after receiving the memorial, conducted an hours-long search at the house of the most outstanding Czech philosopher Karel Kosík, ${ }^{36}$ whose entire research archive, thousands of pages of notes and manuscripts were also confiscated. So far, this was the only reaction to the warnings from Havel." ${ }^{37}$ It is worth adding that J. Lewandowski's analysis was based on numerous quotations from the Václav

\footnotetext{
31 Ibidem p. 82.

32 Ibidem.

33 Ibidem, pp. 82-83.

34 Ibidem, pp. 85-86.

35 Ibidem, pp. 86-87. In addition, J. Lewandowski, in the analysis of the Havel memorial, sought the application of methodological assumptions in the analysis of the recent history of Poland.

36 In the case of K. Kosik, it should be added that his letter to Jean-Paul Sartre on the above-mentioned events was reprinted in "Kultura". K. Kosik, List do Jean-Paula Sartre'a, Praha 26 V 1975, "Kultura" 1975, vol. 11, pp. 76-78.
}

37 J. Lewandowski, op. cit., pp. 87-88. 
Havel memorial, which allowed a Polish-speaking reader to discover his most important theses.

The next text, in which reference was made to the activity of Charter 77, was written by Karl Klatovsky ${ }^{38}$ and was entitled Czesi i Stowacy $w$ latach 1975-1976. ${ }^{39}$ The author explained the circumstances of the announcement of Charter 77 (mentioning that it was originally only signed by the Czechs). He emphasized the very complex composition of the signatories of the document, from the former Minister of Foreign Affairs - J. Hájek, ${ }^{40}$ through former members of the Central Committee of the communist party, poet J. Seifert, ${ }^{41}$ playwright V. Havel, protestant theologians, ending with ordinary workers. I believe that he was very enthusiastic about the date of the Charter disclosure, which was January 1, 1977. He described it as follows: "the date of the manifesto's announcement was well chosen: the New Year does not resemble anything, it is not the date of occupation of Czechoslovakia, no one can be offended. At the same time, it is the day of the traditional speech of the President of the Republic, and thus implies

38 Antonín Měštan (aka Karel Klatovský, born on August 29, 1930 in Prague - died on May 30, 2004 in Freiburg), studied Polish and Russian at Charles University in Prague. He was an employee of the Czechoslovak Academy of Sciences. From 1966 he taught Polish and Czech at the University of Freiburg, where he proceeded through all the stages of his academic career and worked until his retirement in 1995. In 1970s he published his works in immigration magazines under the pseudonym of Karel Klatovský.

39 K. Klatovsky, Czesi i Słowacy w latach 1975-1976, "Kultura” 1977, vol. 4, pp. 127-134.

40 Jiř́i Hájek (born on July 6, 1913 in Krhanice, died on October 22, 1993 in Prague) - he graduated in law from the Charles University in Prague. During the Nazi occupation, he was active in the resistance movement. After the war, he was active in the Communist Party of Czechoslovakia and worked in the diplomacy of the CSSR. In 1968, he became the Minister of Foreign Affairs (he was deprived of this function after the intervention of the Warsaw Pact troops). After the Prague Spring in 1970, he was expelled from the party. After retiring in 1973, he became involved in the activities of the opposition groups, cooperating with Václav Havel on the creation of Charter 77.

41 Jaroslav Seifert (born on September 23, 1901 in Žižkov - died on January 10, 1986 in Prague). In the 1920s, he was associated with the Czechoslovak communist party. He was involved in the changes related to the Prague Spring of 1968. From 1977 he was associated with Charter 77. In 1984 he was awarded the Nobel Prize for Literature. 
polemic with his claims." ${ }^{42} \mathrm{~K}$. Klatovsky also described the reaction of the communist authorities to the announcement of Charter 77 as "very nervous", giving at the same time information about the hearings (including Václav Havel twice), searches and threats posted in the pages of "Rudé právo". He also mentioned the harsh response of the Italian communist newspaper "l'Unita" to Husák's reaction to the signatories of Charter 77, calling for a softening of the regime.

It is also worth quoting $\mathrm{K}$. Klatovsky's personal reflection on the opposition centered around Charter 77 in the CSSR: "nine years after the occupation of Czechoslovakia, it turns out that the occupation has united various currents in Czechoslovakia, of course against Russia. The ones who immediately saw in the occupation the fatal mistake of the Soviet leadership were right. This mistake begins to bear fruit; a new stage in the history of Czechoslovakia has begun." 43

K. Klatovsky continued his analysis in the text Czechostowacja w roku $1977 .{ }^{44}$ First, he cited a number of international initiatives in which he expressed sympathy for Charter 77 and its signatories. These were: the appointment in France of the International Committee for the Defense of Principles of Charter 77 (the initiators were: P. Emmanuel, ${ }^{45}$ G. Martinet ${ }^{46}$ - secretary of the French socialist party and P. Daix ${ }^{47}$ - former communist

42 K. Klatovsky, Czesi i Stowacy..., p. 133

43 Ibidem, p. 134.

44 K. Klatovsky, Czechostowacja w roku 1977, "Kultura” 1978, vol. 1-2, pp. 157-164.

45 Pierre Emmanuel (born on May 3, 1916 in Gan - died on September 22, 1984 in Paris) studied literature at the University of Lyon, and was a French translator, essayist and writer. He was also a member of the French Academy.

46 Gilles Martinet (born on August 4, 1916 in Paris - died on March 29, 2006 in Paris), from the 1930s he was associated with the French communist movement. After the Second World War, he was active in the socialist movement. He was a member of the French Socialist Party. In the years 1981-1984, he was the French ambassador to Italy.

47 Pierre Daix (born on May 24, 1922 in Ivry-Sur-Seine - died on November 2, 2014 in Paris) was a French writer and essayist. He was associated with the French Communist Party and supported the Prague Spring in 1968. From the end of the 1960s, he began to move away from communism in his works. 
publicist), a declaration on January 18 by B. Kreisky, ${ }^{48}$ the Prime Minister of Austria, stating willingness to help persecuted human rights defenders in the CSSR, a declaration on January 20, 1977 by 34 Hungarian intellectuals of their solidarity with Charter 77, the publishing by British newspaper "The Morning Star" on the same day declaring their support for the Czechoslovak opposition. Other examples mentioned by K. Klatovsky are the Norwegian Government's cancelation of invitation for the Czechoslovak Foreign Minister, support for Charter 77 from the Socialist International, or the refusal of the Italian Minister of Foreign Affairs to meet with G. Husák during the change of aircraft at the Prague airport. In turn, on February 1, 1977 in Poland, Jerzy Andrzejewski ${ }^{49}$ informed that the opposition Workers' Defense Committee (KOR) also sympathized with Czechoslovak human rights defenders, while a day later the Danish Communist Party protested against repression of Charter 77 signatories. In February 1977, a series of individual gestures of support appeared. K. Klatovsky mentioned, among others, American composer L. Bernstein his canceling participation in the

48 Bruno Kreisky (born on November 22, 1911 in Vienna - died on July 29, 1990 in Vienna) studied law at the University of Vienna. In the 1930s he was associated with the anti-fascist opposition. After Austria was occupied by the Third Reich, he emigrated to Sweden. In 1951 he returned to Austria. He was then associated with President Theodor Körner. He served on the Austrian National Council (lower house of parliament). He was associated with the Socialist Party of Austria. He held the position of Austrian Chancellor in $1970-1983$.

49 Jerzy Andrzejewski (born on August 19, 1909 in Warsaw - died on April 19, 1983 in Warsaw) studied Polish philology at the University of Warsaw. He published his first texts in the interwar period. After was he was associated with the communist party. In the 60 s he began to sympathize with the opposition circles. In the 70s he was a co-founder of the opposition Workers' Defense Committee. His most popular works are Ashes and diamonds (1948), Darkness covers the Earth (1957), Gates of paradise (1960) or The pulp (1979). In 1968, after the Warsaw Pact invasion, he sent a letter to the president of the Czechoslovak Writers' Union, Eduard Goldstücker (reprinted by “Kultura”). 
Prague Spring music festival ${ }^{50}$ or gestures of sympathy from P. Goma, ${ }^{51}$ a Romanian writer, and M. Dilas. ${ }^{52}$

The gestures of sympathy and solidarity mentioned by the Czechoslovak publicist occurred along with repressions by Czechoslovak communist authorities against opposition activists associated with Charter 77. At this point, K. Klatovsky ${ }^{53}$ pointed out the arrest in Prague of V. Havel, a journalist J. Lederer, a director F. Pavlíček ${ }^{54}$ and a director O. Ornest ${ }^{55}$ (who, according to K. Klatovsky, did not sign Charter 77). ${ }^{56}$ In addition, $\mathrm{K}$. Klatovsky also gave an example of the initiative of the communist au-

${ }^{50}$ Leonard Bernstein (born on August 25, 1918 in Lawrence (USA) - died on October 14, 1990 in New York) was an American composer, pianist and conductor. He was also known as a music critic and author of numerous works on music.

51 Paul Goma (born on October 2, 1935 in Manu - died on March 25, 2020 in Paris), Romanian writer. In the 1970s, he organized the opposition movement in Romania, demanding respect for the constitution and human rights. He supported the creation of Charter 77. In 1977 he left Romania and emigrated to France.

${ }^{52}$ Milovan Dilas (born on 4 or 12 June, 1911 in Podbišće [Montenegro] - died on April 20,1995 in Belgrade). He studied at the University of Belgrade. In the 1930s he was associated with the communist movement. In 1953, he was the vice president of Yugoslavia. He criticized the Soviet intervention in Hungary in 1956. Until the mid-1960s, he was imprisoned many times for criticizing the communist system. The Literary Institute published, inter alia, A new class of exploiters (1957) and Conversations with Stalin (1962).

53 K. Klatovsky, Czechostowacja..., pp. 158-160.

${ }^{54}$ František Pavlíček (born on November 20, 1923 in Lukov - died on September 29, 2004 in Prague). He studied Slavic studies at the Charles University in Prague. From 1950 he worked at Radio Czechoslovakia. After the Prague Spring, he worked as a laborer. He was an author of scripts and radio plays.

55 Ota Ornest (born on July 6, 1913 in Kutná Hora - died on August 4, 2002 in Prague). He studied at the Prague Conservatory. He spent the Second World War in exile in Great Britain. After the war, he returned to Czechoslovakia and until 1972, he was the director of the Municipal Theaters in Prague. He was arrested in 1977 for his relationship with Václav Havel. In the same year (along with Jiří Lederer and Václav Havel) he was charged with importing and distributing forbidden literature. He was sentenced to three and a half years in prison. Fearing for his life, he publicly surrendered to self-criticism. The sentence was reduced by the Supreme Court in 1978 to two and a half years imprisonment. He was then pardoned by Gustav Husák.

${ }^{56}$ K. Klatovsky, Czechostowacja..., pp. 159, 162. 
thorities, which turned into a political farce, as in an attempt to organize a "folk manifestation" in the Prague plant "ČKD", among 14 thousand employees, only 22 people took part in the rally against Charter 77 . On the other hand, he mentioned the tragic event of the death of philosopher J. Patockka, ${ }^{57}$ questioned by the communist police after he was received by the Dutch Minister of Foreign Affairs M. van der Stoel, ${ }^{58}$ during his visit to Prague. In spite of a serious heart disease, J. Patočka was interrogated for so long that he was sent to hospital where he died on February 13, 1977. Also, the funeral of J. Patočka was an opportunity to intimidate the supporters of Charter 77.59

The 70s ended with V. Hejl's ${ }^{60}$ article titled Praga kontrreformacja i refor$m a c j a,{ }^{61}$ in which the Czechoslovak publicist made his remarks regarding

57 Jan Patočka (born on June 1, 1907 in Turnov - died on March 13, 1977 in Prague), one of the greatest philosophers of the $20^{\text {th }}$ century, the founder of Czech phenomenology. The main topic of his considerations was "the natural world". One of his most famous works is Heretical Essays in the Philosophy of History. He is the author of the essay Who are the Czechs? about the national identity of the Czechs. He was involved in the activities of Charter 77. After many hours of interrogation by the StB (Czechoslovakian secret police), he died of a stroke.

58 Max van der Stoel (born on August 3, 1924 in Voorschoten - died on April 23, 2011 in The Hague), studied law at the University of Leiden. He was a Dutch politician, Minister of Foreign Affairs of the Kingdom of the Netherlands. He was associated with the Labor Party. He declared himself an anti-Nazi and anti-communist. In his political activity, he supported the opposition movements in communist countries. In the years 1993-2001 he was the OSCE High Commissioner for National Minorities.

59 K. Klatovsky, Czechostowacja..., p. 160.

60 Vilém Hejl (born on September 24, 1934 in Prague - died January 23, 1983 in Munich), Czech writer and screenwriter. In 1968, he became a co-founder of Club 231, an association of political prisoners sentenced in trials by the communist authorities. He was harassed by the StB (Czechoslovakian secret police). He was a signatory of Charter 77 . He was forced to leave Czechoslovakia. He was active in Radio Free Europe.

61 V. Hejl, Praga, kontrreformacja i reformacja, "Kultura" 1979, vol. 3, pp. 79-90. V. Hejl included his own definition of "Prague Spring", which he considered only a reforming internal party direction, which neither intended to democratize the state nor allowed for a wider participation in the exercise of power by Czechoslovak society. To confirm his thesis, he referred to the published materials of the $14^{\text {th }}$ Congress of the Communist Party of the CSSR, which took place in September 1968, in which it was stated that the model 
Charter 77, considering it as something, "more" than just the aftermath of the so-called Prague Spring. In his opinion, Charter 77 is both a continuation of the Czech democratic tradition ${ }^{62}$ as well as the defense of human rights in the era of the existence of the communist system in Czechoslovakia. In his essay, V. Hejl stressed the principles of defense of national culture, appearing in the slogans and activities of the Charter 77 signatories, recognizing as the first person the official (and critical) analysis of the official cultural policy made by V. Havel in his open letter to G. Husák (what is also mentioned in this text). ${ }^{63}$

Czechoslovak publicist V. Hejl, based on the analysis of previous opposition activities (also from the Habsburg period), highly rated the activities of Charter 77, and seemed to (based on the text quoted above) have great hopes for it. The opposition centered around Charter 77 was not, as before, an anonymous opposition, but a public opposition and thanks to "[...] this transparency, it enjoyed much of its moral authority in society." ${ }^{4}$ In addition, the difference from other opposition forms in Czechoslovakia was the fact that its aim was not a coup or destruction of the existing legal order, but to strive that legal order be respected. At this point, V. Hejl added that it was very difficult to explain to the leftist intellectuals that the aim of the activity was law and order. Of course, in the example of the legal order of Czechoslovakia, it can be seen that calling for its respect has a twofold character. On the one hand, the Charter 77 signatories called on the communist authorities to respect the Covenant on human and civil rights, ${ }^{65}$ on the other hand they called on both the communist authorities and the

of the party's monopoly of power was to be still protected by law. He added that in the evaluation of ex-communists, the year1968 was the so-called "zero year" - ibidem, p. 83.

62 In the case of continuation of "democratic traditions", V. Hejl pointed to T. Masaryk and K. Havlíček.

63 V. Hejl, op. cit., p. 86. It happened, of course, before the disclosure (announcement) of Charter 77. In turn, V. Hejl considered the Charter 77 signatories' call for dialogue with representatives of the communist regime as quixotism - ibidem, p. 88.

64 Ibidem, p. 89.

65 Probably it was the International Covenant on Civil and Political Rights - a treaty adopted as a result of the UN conference based on the resolution of 16 December 1966, No. 220A (XXI). 
Czechoslovak society to respect the constitution of Czechoslovakia. And it was this second point (i.e. respect and observance of the constitution) that caused a very serious problem, as a result of which many people refused to sign Charter 77. However, according to V. Hejl, the lack of acceptance of the constitution was more serious for the communist regime. ${ }^{66}$

Hejl devoted a separate point to the attitude of the West to the opposition in the CSSR, stating that nobody expected any specific help or intervention unless it was assistance that would somehow benefit the West. ${ }^{67}$

\section{Opposition in Czechoslovakia in the 1980s}

The issue of the opposition in Czechoslovakia and Charter 77 was also discussed in the journalism of the 1980s, in a diametrically different reality. The first half of 1980 was marked by strikes at Polish production plants, in particular the Lenin Shipyards in Gdansk. The agreements signed with the government in August 1980 guaranteed the registration of the independent trade union Solidarity and ensured a number of changes in the then Polish socialist legislation. 500 days of the so-called carnival of Solidarity began and while acting legally on the Polish political scene, it had an impact on the functioning of the state. The changes taking place in Poland affected other European socialist countries, including opposition circles in Czechoslovakia. Unfortunately, every carnival comes to an end. In this case, it was thwarted with the introduction on December 13, 1981, of martial law by the Polish communist authorities. The journalism presented in the pages of "Kultura" in the early period of the 80 s referred to the events that took place then in Poland.

One of the first texts that appeared in the emigré journal "Kultura" in the next decade of communist rule in both countries was a piece by $\mathrm{P}$. Tigrid $^{68}$ entitled Jak pomagać dysydentom? (How to help dissidents?). However,

66 V. Hejl, op. cit., p. 90.

67 Ibidem.

68 Pavel Tigrid (born on October 27, 1917 in Prague - died August 31, 2003 in Héricy, France). He studied law at Charles University in Prague. He spent the Second World War in London. He then became involved with the BBC. In the years 1945-1948 
it was not an article that was created specially for the Literary Institute, but a reprint from the French journal "Le Monde" of December 19, 1979. ${ }^{69}$

Another noteworthy text was J. Lederer's Historyczne doświadczenia (Historical experiences). ${ }^{70}$ The topic related to Charter 77 and the Czechoslovak opposition in the 1970s was examined on the basis of the analysis of Polish-Czechoslovak relations. Although the Polish People's Army was part of the Warsaw Pact troops who conducted the invasion in 1968, J. Lederer stated that the 1970s were breakthrough years for Poles, Czechs and Slovaks: "the year 1968 convinced Poles that we can be trusted as partners in the fight for a better tomorrow, and the 1970s convinced our citizens that

he lived in Czechoslovakia, was active in the Czechoslovak People's Party and worked in the Ministry of Foreign Affairs. After 1948 he lived in exile. He joined Radio Free Europe. While in exile, he published the magazine Svědectví (sometimes considered the Czechoslovak equivalent of the Parisian "Kultura"). After 1990 he returned to Czechoslovakia. At that time, he was the Minister of Culture and the President's Advisor on Czech-German relations.

69 P. Tigrid, Jak pomagać dysydentom?, "Kultura" 1980, vol. 1-2, pp. 76-80. Under the text, the Editorial Office of Kultura, in addition to providing information about the author, placed the following statement: "By posting this interesting and proper article, we do not agree with all the author's arguments. The transparency of the opposition activity has great advantages, but also entails a great danger. The same refers to conspiracy. It seems right to us to use the same methods at the same time. Likewise, it seems to us wrong to emphasize the defensive nature of opposition movements. Defense is not enough. And not all opposition movements apply it." - ibidem, p. 80.

70 J. Lederer, Historyczne doświadczenia, "Kultura" 1981, vol. 1-2, pp. 123-129. See also other J. Lederer's texts on Poland during martial law: Polska i Europa, "Kultura" 1981, vol. 11, pp. 45-49 and Trzecia normalizacja, "Kultura" 1982, vol. 11, pp. 73-81. In addition, what appeared in the pages of "Kultura" was a review of the book by J. Lederer, $M e ́$ Polsko. 200 let boje proti cizi nadvládè, Index publishing house, Federal Republic of Germany, 1982 - see J. Mondry, Polska Jiri Lederera, "Kultura" 1982, vol. 12, pp. 129-131. In the text Historyczne doświadczenia, Lederer, on the example of political changes that took place in Czechoslovakia in the then decades, showed how the Czechs and Slovaks' attitude towards Russians changed, that is from the sympathy that the Czechoslovak intelligentsia had for Russia in the $19^{\text {th }}$ century, through the fascination with the October Revolution, ending with hatred and reluctance after a radical change in the political system, especially after the invasion of the Warsaw Pact armies in 1968. J. Lederer also included in this text his remarks on the system of government in 1969, including the communist party of the CSSR as well as the people of A. Dubček - J. Lederer, Historyczne..., pp. 123-127. 
Poles are the most persistent and consistent fighters against the totalitarian regime [...]." ${ }^{71}$ He strongly emphasized the cooperation between Charter 77 and the Polish Workers' Defense Committee (commonly known as the KOR). He characterized their activities as follows: "Charter 77 and KOR gather people who do not violate the established legal order in their countries, who only fight for the ruling groups to respect existing legal norms [...]." ${ }^{\prime 2}$ In addition, J. Lederer outlined the atmosphere that prevailed after the creation of Charter 77 as well as the policy of government and party authorities manifested in aggressive propaganda against the founders and Charter 77 activists. In turn, further activities of the Charter 77 and KOR manifested by meetings caused surprise and concern in both communist countries. However, J. Lederer, mentioning the actions of the security services, added that the Czechoslovak militia "was more ingenious and brutal in its actions." 73

Cooperation between KOR and Charter 77, as J. Lederer stated, was not only a bilateral cooperation. Entities and persons who dealt with human rights in Central and Eastern Europe sought ways towards common agreement, despite the fact that the USSR policy was aimed at dividing the nations that were in their political zone. ${ }^{74}$

71 Ibidem, p. 127. In addition, J. Lederer, in the relations between the two countries, saw a great chance for change in Europe, claiming that "cooperation between Poles and the Czechoslovaks can become a factor affecting events across the continent in the future" ibidem.

72 Ibidem, p. 128. J. Lederer made an interesting observation regarding the legal systems of democratic states, claiming that all systems have "legally, formally democratic standards, but only formally". In addition, they very willingly subscribe to declarations of human rights, as exemplified by the Helsinki Final Act, but they never intend to take their signatures seriously or respect them - ibidem.

73 Ibidem.

74 Ibidem. J. Lederer also made remarks about the changes that took place then in Central and Eastern Europe. Starting from the events in the CSSR in 1968, as well as events in Poland in the 1970s, he considered them to be more important than events that occurred in the 1950s in the GDR, Poland or Hungary: „The events in Poland in 1980 were thought to be a special episode that exposed the communist authorities because: „[...] the driving force is the working class, this class which defines all proclamations of the communist parties as the foundation of the socialist system" - ibidem, p. 129. As 
Another text, also by J. Lederer, in which he referred to Charter 77 and its activities, appeared in "Kultura" in $1983 .{ }^{75}$ In this material, Lederer recalled the circumstances of the creation of Charter 77, characterizing at the same time its two leading figures, that is V. Havel and J. Patočka: "[...] the first far from any religion, the second deeply connected with Christianity. These two people decided about the spirit of the new movement and became its most famous spokespersons." ${ }^{76}$ Lederer emphasized the "spirit of tolerance" prevailing in the environment of Charter 77, as exemplified by a very large social, age, political or intellectual discrepancy of its sympathizers. In addition, he described the movement of Charter 77 as follows: "[...] it is like a voice of conscience coming from and addressed to society." "77 According to him, the main message of Charter 77 was that everyone should demand that the government respect the constituted legal norms, and "if one would like to demand more from it, they direct their demands at the wrong address." 78 J. Lederer also described the policy of the communist authorities of Czechoslovakia directed towards Charter 77 and its supporters, mentioning the largest press campaign in the world since the 1950s defaming the supporters of Charter 77. However, as he recognized, it was an "excellent advertisement" thanks to which Charter

a consequence, the dictatorship of the proletariat turned into an empty word. In connection with the introduction of martial law in Poland in 1981, the text entitled Czesi wobec wydarzen $w$ Polsce was published in "Kultura", which included criticism of the policy of the Polish communist authorities as well as expressed sympathy with the Polish nation. The text was signed by: J. Pelikán, Z. Mlynáŕ, Z. Hejzlar, A. Müller and M. Raiman - see Czesi wobec wydarzeń $w$ Polsce, "Kultura" 1982, vol. 6, pp. 94-95.

75 J. Lederer, Karta 77 i chrzéśijanie, "Kultura" 1983, vol. 6, pp. 126-130.

${ }^{76}$ Ibidem, p. 126. In addition, as the basis, that is the activities preceding the appearance of Charter 77, the Czechoslovak émigré publicist pointed to four points: the appearance of discussion groups in private apartments, the publication of the so-called samizdat, an example of which was a journal edited by L. Vaculík titled Petlice, the development of émigré journals such as Listy, Svedectvi or Studie, and the growth in popularity of radio programs broadcast in Polish and Czech by Radio Free Europe, BBC or Voice of America - ibidem, p. 128.

77 Ibidem, p. 127.

78 Ibidem. 
77 became widely known, and the number of its signatories was constantly growing. ${ }^{79}$

In turn, the 1970s, as J. Lederer claimed, were not all about Charter 77 and the activation of the society around its ideals, but also the revival of the Catholic religion in Czechoslovakia. He added that "the irony of fate and history has led to the situation in which former communists and Christians together are fighting for spiritual and social renewal." ${ }^{80}$ Anticipating the question of a potential reader who could accuse J. Lederer of too much attachment to Charter 77 as well as the renaissance of religion in the CSSR, he briefly described the history of the Catholic religion in the Czech Republic, when in the late $19^{\text {th }}$ century, the society began to be dominated by anti-Church accents, while the Church was removed from national life (as opposed to Poland). In turn, the interwar period, in relations between the Church and the state, was characterized by the slogan "farther from Rome". The communists, on the other hand, not only continued their policy of separating the state from the Church, but also began to apply a series of persecutions. ${ }^{81}$ On the basis of his reflections on Charter 77 and the Christian religion in the CSSR, Lederer set forth the following thesis: "The 70 s are a breakthrough. Religion is no longer seen as the expression of backwardness. Even non-believers are beginning to understand - their accession to Charter 77 is often an expression of this - that where religion is oppressed and persecuted, people are oppressed and persecuted there for their beliefs." ${ }^{2}$

79 Ibidem. In his text, J. Lederer divided the forces associated with Charter 77 into two groups: ex-communists - people once associated with the Communist Party and Christians (both Catholics and Protestants). Lederer included the following people in the latter group: V. Malý and M. Rejchter, (the first is a Catholic priest, the other is an Evangelical priest, both were forbidden to perform priestly services). Other people mentioned are: J. Trojan - Evangelical theologian, B. Komárková - Protestant, M. Rút Kř́ržková - Catholic activist, F. Lizna - Catholic priest and J. Zvěřina - Catholic theologian. Lederer also quoted a letter by a former communist, which he received in 1981, in which the dramatic situation of Charter 77 , its surveillance by the security services and the exceptional and heroic attitude of believers were described - ibidem, p. 128.

80 Ibidem, p. 129.

81 Ibidem.

82 Ibidem, pp. 129-130. Moreover, it should be added that in the presented text, 
Regarding the Polish-Czechoslovak cooperation in terms of opposition, as mentioned by J. Lederer writing about Charter 77 and KOR, the Editorial Office of "Kultura" presented another form of activity, namely Polish-Czechoslovak Solidarity. The activities of the new form of cooperation were presented in the form of an interview conducted by W. Szukalski ${ }^{33}$ with M. Jasiński. ${ }^{84}$ One major drawback is the lack of any voice from the Czechoslovak side. In an interview, M. Jasiński introduced the circumstances of the emergence of the Polish-Czechoslovak solidarity, dating back to 1981. He described the beginning of cooperation between the representatives of Charter 77 and Solidarity and the establishment of a cooperation agreement. Initially, it was to be the Polish-Czech Solidarity, but in 1982, the initiative was extended to include Slovak side. The circumstances were not favorable for the development of the new movement, because in Poland martial law prevailed and in the CSSR the environment of Charter 77

J. Lederer made brief remarks regarding the then existing situation in Europe. He came to a conclusion that the 1970s were the beginning of the Czech recrystallization era, which would translate into mutual relations between the Czechs and Slovaks as well as the Czechs and Poles. In turn, Charter 77 and the renaissance of Christianity were to indicate the breakup of Europe. Both the western and eastern parts of Europe were facing radically different problems. However, it was in Eastern Europe where the forces striving to live in democracy and political order were born. In turn, Western Europe was to be characterized, according to Lederer, by "lack of trust in democracy, that is, a retreat from civilization" ibidem, p. 130.

83 Wojciech Maziarski (born on January 24, 1960 in Chorzów - from 1981 pseudonym Wiesław Szukalski), graduate of the Chair of Hungaristics at the Faculty of Modern Languages of the University of Warsaw, opposition activist, editor of the "Obóz" magazine. He collaborated with the monthly "Niepodległośc", the Parisian "Kultura" and "Tygodnik Mazowsze". From 1986, he was active in the Polish-Czechoslovak Solidarity. In 1989, he co-organized the Polish-Hungarian Solidarity.

${ }^{84}$ Mirosław Jasiński (born on December 12, 1960 in Bolesławiec), a graduate of Polish philology and art history at the University of Wrockaw. He was associated with the Polish-Czechoslovak Solidarity. On April 16, 1987, he participated in a demonstration in Wrocław in defense of the Charter 77 activist, Petr Pospíchal, arrested in Czechoslovakia. On November 3-5, 1989, he co-organized the Review of Independent Czechoslovak Culture in Wrocław; Nie tylko hasto. Interview with Mirostaw Jasinski, representative of Polish-Czechoslovak Solidarity (interview was conducted by Wiesław Szukalski), "Kultura" 1988, vol. 9, pp. 56-63. 
was decimated by numerous lawsuits and repressions by the communist authorities. The original cooperation was to be based on the exchange of information. M. Jasiński mentioned the documents received from the Czechoslovak side, in which the Czechs very precisely compared repressive legislation of Husák and that of the Military Council of National Salvation (WRON). ${ }^{85}$ Other information provided by the Czechoslovak website was detailed information about the visit of General W. Jaruzelski ${ }^{86}$ in the CSSR, an indication of a potential camp in northern Bohemia where members of the Polish opposition could be transported. ${ }^{87}$ In turn, the Polish side was thought to have sent illegal publications to the CSSR. In Jasiński's opinion, in the years 1986-87, from about half a ton to a ton of so-called tissue paper was transported. Another Polish initiative that revealed the activities of the Polish-Czechoslovak Solidarity was connected with the arrest of Petr Pospíchal. ${ }^{88}$ Prayers were recited for him during Mass in Podkowa Leśna and on April 16, 1987, a demonstration took place in Wrocław and signatures were collected for a petition in his defense. In turn, the main activity of Solidarity focused on publishing the Information Bulletin in the pages of which the names of persons detained, arrested and convicted as well as assistance to persons imprisoned for political activity or their families were presented. ${ }^{89}$

85 WRON - the abbreviation of the Military Council of National Salvation - the body appointed at the time of the introduction of martial law, which administered Poland during its course, that is from December 12, 1981 to July 21, 1983.

86 Wojciech Jaruzelski (born on July 6, 1923 in Kurów - died on May 25, 2014 in Warsaw), Polish communist politician associated with the Polish United Communist Party, Minister of National Defense in 1968-1983, Prime Minister in 1981-1985, First Secretary of the Central Committee of the Polish United Workers' Party in 1981-1989 and President of the People's Republic of Poland in 1989-1990.

87 Nie tylko hasto. Interview..., pp. 57-58. M. Jasiński did not remember the name of the town where this potential camp could be found. He said that it was between the uranium mines and was called "the Czech Alcatraz".

88 Petr Pospíchal (born on April 16, 1960 in Brno), signatory of Charter 77, activist of Polish-Czechoslovak Solidarity. He was detained and arrested several times, among others, in 1987 in Brno on charges of distributing forbidden literature. A demonstration in Wrocław was organized in his defense.

89 Nie tylko hasto. Interview..., pp. 58-59. 
It is worth mentioning M. Jasiński's remarks concerning Charter 77. In his opinion, despite the crisis in its activities after 1984, Charter 77 gained new momentum. It resulted from the fact that in 1983-84, a significant number of the arrested activists served the sentences adjudicated to them. This was confirmed by the increased publishing movement. In 1982, only one journal was published - "Informace o Chartě 77" - and according to Jasiński, several years later there were about ten titles. He also analyzed the Czechoslovak resistance movement and identified three trends therein: the democratic opposition - centered around Charter 77, the underground movement - originating from the Hippie movement, and the religious movement - very active in Slovakia and Moravia (Fr. V. Malý, ${ }^{90}$ one of the co-founders of the Polish-Czechoslovak Solidarity, originated from this movement). ${ }^{91}$

List 271 Obywateli Czechostowackich (the Czech title: Dopis 271 čs. obćanu), drawn up in Prague on 15 August 1988, which was previously published in "Informace o Chartě 77", No. 17 from 1988, was also placed on the pages of "Kultura". ${ }^{92}$

It is also worth mentioning the calendar of events that took place from November 17, 1989 to December 20, 1989 in Czechoslovakia (that is, until Václav Havel was elected President of Czechoslovakia). ${ }^{93}$

\section{The Czech and Slovak Chronicle}

Accents on the Czechoslovak opposition can be found in Kronika czeska $i$ stowacka (The Czech and Slovak Chronicle). It should be clarified that the pages of "Kultura" included sections entitled The Chronicle referring to other states and peoples (e.g. The Czech and Slovak Chronicle, The German

90 Václav Malý (born on September 21, 1950 in Prague), Roman Catholic priest, auxiliary bishop of Prague. He was ordained priest in 1976. He was associated with Charter 77. In 1980-1989 he worked as a surveyor and fireman, secretly working as a priest. In the years 1981-1982 he was the spokesman for Charter 77.

91 Nie tylko hasto. Interview..., p. 60.

92 List 271 obywateli czechostowackich, "Kultura" 1989, vol. 1-2, pp. 120-122.

93 (amp), Jesień praska 1989, “Kultura” 1990, vol. 3, pp. 100-105. 
Chronicle, The Baltic Chronicle). These were not cyclical publications and did not constitute permanent editorial sections presented in every issue of "Kultura". Moreover, the information contained there was most often one or a few sentences long, without any analysis or comment (as was the case with the texts previously presented).

From the outset of the process of the so-called "normalization", information about the repression by Gustav Husak's team appeared in The Chronicle. For example, there were reports of harassment against Catholics, ${ }^{94}$ Ludvik Vaculik ${ }^{95}$ and others associated with the Prague Spring, ${ }^{96}$ Fr. Viktor Trstenský ${ }^{97}$ and Zdeněk Mlyná. ${ }^{98}$

94 D. M. (actually D. Morawski), Kronika stowacka, "Kultura" 1975, vol. 9, pp. 90-92; A. Tomsky, Kronika czeska i stowacka, "Kultura" 1983, vol. 3, pp. 120-121; idem, Kronika czeska i stowacka, "Kultura" 1983, vol. 6, pp. 133-134; idem, Kronika czeska i stowacka, "Kultura" 1983, vol. 7, pp. 133-134; idem, Kronika czeska i stowacka, "Kultura" 1983, vol. 10, pp. 123-124; idem, Kronika czeska i stowacka, "Kultura" 1984, vol. 1, pp. 146-147; idem, Kronika czeska i stowacka, "Kultura” 1985, vol. 1, pp. 168-170.

95 Ludvik Vaculik (born on July 23, 1926 in Brumov - died on June 6, 2015 in Dobřichovice). Czech prose writer, associated with Czechoslovak radio in the 1950s. In 1965 he became editor of Literárni Listy and Listy. In June 1968, he wrote the "Two Thousand Words" manifesto referring to reforms relating to the Prague Spring. With the entry of the Warsaw Pact troops, he issued the "Ten Points" manifesto. In the 1970s and 1980s, he was associated with the Czechoslovak samizdat and published in the Western European press.

96 G. H. Kronika czeska i stowacka, "Kultura" 1975, vol. 7-8, pp. 144-145.

97 Viktor Trstenský (born on March 28, 1908 in Trstená - died on December 7, 2006 in Trstená), a Slovak Roman Catholic priest. In his priestly work, he opposed the communist regime, for which he was imprisoned many times. He was associated with the opposition movement in Czechoslovakia; D. M. (actually D. Morawski), Kronika stowacka, "Kultura" 1975, vol. 10, pp. 103-107.

98 Zdeněk Mlynář (born on June 22, 1930 in Vysoké Mýto - died on April 15, 1997 in Vienna). In 1946 he became an activist of the Communist Party of Czechoslovakia. A graduate of law studies at the Lomonosov Moscow State University. In Czechoslovakia, he worked at the Czechoslovak Academy of Sciences and at the Charles University in Prague. A supporter of reforms in 1968. During the process of the so-called normalization, he was removed from the communist party. From 1977 he lived in exile in Austria. Then he published his work entitled Mráz pricházi z Kremlu - a collection of his memories. He was a signatory of Charter 77; K. Szwedowicz, Praca Zdenka Mlynarza-Kronika czeska, "Kultura" 1975, vol. 10, pp. 110-111. 
Regarding the activities of Charter 77, in The Chronicle, A. Tomsky (aforementioned in this text) announced the arrest of Ladislav Lis, ${ }^{99}$ one of the spokespeople of Charter 77, forcing the Charter 77 activists to leave Czechoslovakia $^{100}$ as well as V. Havel's illness in prison and his suspension from prison for this reason, ${ }^{101}$ the appointment of Marie Rút Krŕžzová ${ }^{102}$ as spokesperson for Charter 77, the petition concerning the release of Jaromír Šavrda, ${ }^{103}$ V. Havel's interview for "Le Monde", in which he talked about his stay in prison, ${ }^{104}$ Fr. Václav Benda's release from prison ${ }^{105}$ (associated with the Committee for the Defence of the Unjustly Persecuted VONS), ${ }^{106}$ the sentencing of L. Lis by the court in Usti nad Labem to 14 months

99 Ladislav Lis (born on April 26, 1926 in the village of Mlaka - died on March 18, 2000 in Sosnová). After the Second World War he was connected with the Communist Party of Czechoslovakia, from which he was expelled in 1960. He was readmitted in 1968. A supporter of the Prague Spring reforms. He was expelled from the party again in 1969. He graduated in law from the Charles University in Prague. He was associated with Charter 77 (for which he was a spokesman), the Committee for the Defense of the Unjustly Persecuted (VONS) and the Czechoslovak samizdat. During the Velvet Revolution, he was active in the Civic Forum.

100 A. Tomsky, Kronika czeska i stowacka, "Kultura" 1983, vol. 6, p. 134.

101 Idem, Kronika czeska i stowacka, "Kultura" 1983, vol. 4, pp. 106-107; idem, Kronika czeska i stowacka, "Kultura" 1983, vol. 6, p. 134.

102 Marie Rút Křížková (born on June 15, 1936 in Miličín - died on December 4, 2020 in Čerčany). A graduate of the Faculty of Arts at the Charles University in Prague. She was a signatory and spokesperson for Charter 77.

103 Jaromír Šavrda (born on May 25, 1933 in Ostrava - died on May 2, 1988 in Ostrava). A graduate of the Faculty of Fine Arts at the Charles University in Prague. He worked as a journalist and teacher. During the normalization period he was associated with the Czechoslovak samizdat and Charter 77. The founder of the Society of the Friends of the United States. He was arrested for opposition activities.

104 A. Tomsky, Kronika czeska i stowacka, "Kultura" 1983, vol. 6, p. 134.

105 Václav Benda (born on August 8, 1946 in Prague - died on June 2, 1999 in Prague). A graduate of Philosophy, Bohemian studies and Cybernetics at the Charles University in Prague. He was associated with Charter, 77 (for which he was a spokesman), the Committee for the Defense of the Unjustly Persecuted (VONS) and the Czechoslovak samizdat. He was convicted for opposition activities. During the Velvet Revolution, he was active in the Civic Forum.

106 A. Tomsky, Kronika czeska i stowacka, "Kultura” 1983, vol. 10, p. 122. 
imprisonment, and the issuance by Charter 77 of a statement demanding the withdrawal of Soviet troops from Czechoslovakia in connection with the youth demonstration in Pisek. ${ }^{107}$

In $1985,{ }^{108} \mathrm{~A}$. Tomsky reported that Solidarity and Charter 77 activists in 1984 made a joint appeal to the Czechoslovak and Polish authorities demanding the release of political prisoners. In this regard, information was provided on: (reported in the Western European press) the large time gap between the last meetings of the activists of the Workers' Defence Committee (KOR) and Charter 77, another conviction of L. Lis in May 1984 for leaving his home without the permission of the militia between 5 and 9 May 1984 (L. Lis was under the supervision of the militia until June 1987), Charter 77 activists arrested in connection with the upcoming anniversary of the invasion by the Warsaw Pact troops (including V. Havel, who was awarded an honorary doctorate at the University of Toulouse and whose play was staged on Broadway) and the open letter from Charter 77 To Polish friends expressing sympathy in connection with the tragic death of Fr. Józef Popiełuszka ${ }^{109}$ (the following excerpt was quoted from this letter: "From our own experience, we understand perfectly well that there would be no terrorist groups if they had not been inspired by a general violation of the law and if they had not had the support of the highest authorities"). ${ }^{110}$

In the late 1980s, The Czech and Slovak Chronicle reported on: Pavel Wonka's ${ }^{111}$ death in Hradec Kralove prison (as reported by "Kultura" he

107 Idem, Kronika czeska i stowacka, "Kultura” 1984, vol. 1, p. 147.

108 Idem, Kronika czeska i stowacka, "Kultura" 1985, vol. 1, pp. 168-170.

109 Jerzy Popiełuszko (born on September 14, 1947 in Okopy - died on October 19, 1984 in Włocławek) Polish Roman Catholic priest. The "Solidarity" chaplain and the initiator of the so-called Mass for the Homeland. He was murdered (by drowning and earlier torture) by officials of the Ministry of the Interior for his activities and being associated with the opposition. To this day, the entire circumstances related to the ordering of his death remain unknown.

110 A. Tomsky, Kronika czeska i stowacka, "Kultura" 1985, vol. 1, p. 170.

111 Pavel Wonka (born on January 23, 1953 in Vrchlabí - died on April 26, 1988 in Hradec Králové). He was associated with the Czechoslovak opposition (although he was not a signatory of Charter 77) for which he was sentenced to imprisonment. He died in prison in Hradec Králové during a hunger strike. His funeral turned into a political demonstration. 
was sentenced to 21 months in prison and 3 years of militia supervision for trying to stand for election to the Czechoslovak Parliament, his death was announced by his mother and not by the prison authorities) and the reaction of the International Helsinki Federation for Human Rights demanding an explanation of the reasons for his death, ${ }^{112}$ the new spokespeople of Charter 77, who were: Stanislav Devátý, ${ }^{113}$ Miloš Hájek, ${ }^{114}$ Bohumír Janát, ${ }^{115}$ replacing the former spokespeople - Jan Litomiský ${ }^{116}$ and Libuše

112 A. M. P., Kronika czeska i stowacka, "Kultura" 1988, vol. 6, p. 119; idem, Kronika czeska i stowacka, "Kultura" 1988, vol. 9, p. 114. In honor of P. Wonka, an opposition organization called the Legal Aid Club was established - see idem, Kronika czeska i stowacka, "Kultura" 1989, vol. 7, p. 181. In the case of The Czech and Slovak Chronicle, led by a person with the initials A. M. P., a certain rule can be observed. In the first part, information about opposition activities was presented. At the end, in turn, several facts relating to Czechoslovakia itself were presented. (In the case of The Czech and Slovak Chronicle created by a "Kultura" journalist who signed it with the initials A. M. P, a certain regularity can be observed. First, the opposition activities in Czechoslovakia were presented, followed by information about Czechoslovakia itself.)

113 Stanislav Devátý (born on June 8, 1952 in Zlín [formerly Gottwaldov]). He was associated with Charter, 77 (for which he was a spokesman), the Committee for the Defense of the Unjustly Persecuted (VONS) and the Czechoslovak samizdat. He was arrested for his political activities. In 1988-1989 he was a spokesman of Charter 77. He actively participated in the political life of Czechoslovakia in 1989 (and then the Czech Republic).

114 Miloš Hájek (born on May 12, 1921 in the village of Dětenice - died on February 25, 2016 in Prague), his wife was Alena Hájková, with whom he organized aid for Jews during the Second World War. At that time, he was associated with the Czechoslovak resistance movement. After the war, he was active in the Communist Party of Czechoslovakia, from which he was expelled after the intervention of the Warsaw Pact troops in 1968. Then he was associated with Charter 77, for which he was persecuted by the communist authorities of Czechoslovakia.

115 Bohumír Janát (born on November 7, 1949 in Tábor - died on November 29, 1999 in Prague). He graduated in Philosophy and Psychology at the Charles University in Prague. In the 1970s, he worked at the Czechoslovak Academy of Sciences, from which he was dismissed for his activities under Charter 77.

116 Jan Litomiský (born on August 19, 1949 in Prague). He comes from a farming family whose agricultural property was confiscated in the 1950s. He graduated from the Agricultural University in Prague. He was associated with the Czechoslovak People's Party for a short period of time, then Charter 77 (for which he was a spokesman) and the Committee for the Defense of the Unjustly Persecuted (VONS). In the 1980s, he was arrested 
Šilhánov, ${ }^{117}$ collecting signatures on petitions demanding respect for religious freedoms and separation of Church and state, the letter from Charter 77 activists to the societies of the states whose troops participated in the invasion of August 1968 in order to organize initiatives to draw attention to the illegality of this intervention, the failed meeting of the representative of the British Ministry of Foreign Affairs David Radford with the Charter 77 activists at the British Embassy (on the day of the meeting, the Charter 77 activists were detained and, according to the information given by "Kultura", Stanislav Devátý and Petr Uhl, ${ }^{118}$ who also arrived at the meeting were detained after it), the meeting between Petr Pilz ${ }^{119}$ of the Austrian Green Party and the Charter 77 activists in Prague on 16 and 17 March 1988 on the construction of a hydroelectric power plant on the Dunajec river on the Czechoslovak-Hungarian border, ${ }^{120}$ the death of Zdeněk Urban, a Charter 77 activist, on 13 May 1988, the $4^{\text {th }}$ Charter 77 Forum held in Prague restaurant U České Koruny interrupted by the intervention of the secret police and the detention of participating activists as well as the organization of a seminar entitled Praha 88 by Charter 77 and the Independent Peace

for opposition activities. He actively participated in the political life of Czechoslovakia after the Velvet Revolution.

117 Libuše Šilhánová (born on April 10, 1929 in Vrdy - died on October 10, 2016 in Prague). A graduate of the Faculty of Arts at the Charles University in Prague. She worked as a teacher for many years. She was active in the Communist Party of Czechoslovakia, from which she was expelled in 1970 for criticism of occupation of Czechoslovakia by Soviet troops. She participated in activities of Charter 77 and the Czech Helsinki Committee.

118 Petr Uhl (born on October 8, 1941 in Prague). A graduate of the Czech University of Technology. After the intervention of the Warsaw Pact troops, he was convicted of subversion against the communist authorities of Czechoslovakia. He was associated with Charter 77. In 1989 he worked as editor of the Eastern European Information Agency. It was then that he passed on information about the death of a student, Martin Šmíd, which turned out to be a rumor and triggered a series of demonstrations contributing to the Velvet Revolution. After 1989, he actively participated in the political life of Czechoslovakia (and then the Czech Republic).

119 Peter Pilz (born on January 22, 1954 in Kapfenberg). A graduate of Social and Economic Sciences at the University of Vienna. A politician of the Austrian Green Party. He also worked as a sociologist and journalist.

120 A. M. P., Kronika czeska i stowacka, "Kultura" 1988, vol. 6, pp. 118-120. 
Group, attended by representatives from Poland, Hungary and Yugoslavia ("Kultura" announced the proposal to create an international parliament for peace movements - the European Assembly for Peace and Democracy based in Prague as well as an initiative that the States participating in the intervention in August 1968 should admit that it was contrary to international law). ${ }^{121}$

In the case of the $20^{\text {th }}$ anniversary of the Warsaw Pact troops' intervention in Czechoslovakia, in The Czech and Slovak Chronicle, a demonstration in Wenceslas Square in Prague was announced (this included information about the demonstration broadcast on television and the lack of intervention by the militia until the demonstrators headed towards Prague Castle). In addition, Charter 77 issued a statement to the Czechs and Slovaks "[...] to shed the burden of fear and to speak freely about the intervention of 21 August 1968 and the policy which it brought [...]", and in the case of the initiators of the intervention, they were called out to "[...] come out of their anonymity and explain their conduct [...]"; whereas the USSR was called on "[...] to break taboos and create the rationale for an objective judgement of the Soviet Union's co-responsibility for the fate of Czechoslovakia at that time"). ${ }^{122}$ The section on the anniversary of the intervention of 1968 also mentions: the conviction of Ivan Polanský, ${ }^{123}$ a Slovak Catholic activist, for storing illegal religious literature, the activities of Petr Uhl, who accused Vasil Bilak ${ }^{124}$ (Slovak Communist, supporter of the intervention of 1968, one of the so-called "hardliner" activists in communist Czechoslovakia)

121 Idem, Kronika czeska i stowacka, "Kultura" 1988, vol. 9, p. 114.

122 Idem, Kronika czeska i stowacka, "Kultura" 1988, vol. 11, p. 125.

123 Ivan Polanský (born on March 22, 1936 in Žilina - died on December 27, 2015 in Dubnica nad Váhom). He worked as a technician and printer in Dubnica nad Váhom. He was a Slovak Catholic activist. He published in the Czechoslovak samizdat. He was convicted of opposition activity. After 1989, he actively participated in the political life of Czechoslovakia and then the Slovak Republic.

124 Vasil Bilak (born on January 11, 1917 - died on February 6, 2014 in Bratislava). He was an activist of the Communist Party of Czechoslovakia and the Communist Party of Slovakia. From April 1968 to December 1988, he was a member of the Presidium of the Central Committee of the Communist Party of Czechoslovakia. A supporter of military intervention in 1968. He was expelled from the party in December 1989. 
for being a terrorist and trying to organize attacks on people, Petr Uhl's letter to the editor of the communist magazine "Rudé právo", in which he demanded the rectification of information given in 1969 that he was preparing a coup and an attack on the Prague broadcaster (Petr Uhl's initiative was to be supported by his 42 friends who sent an open letter to the editor), A Charter 77 memorandum addressed to the Czechoslovak authorities and the International Labour Organization regarding discrimination against workers on the basis of their political views (examples were teacher Helena Kamanova who was discriminated against for possessing religious literature and admitting to attending religious services as well as teacher Jana Mičanova discriminated for sending children to church) and the Scientific Symposium Czechoslovakia 88 organized by Charter 77 and held from 11 to 13 November $1988 .{ }^{125}$

A day before the Velvet Revolution of 1989, The Czech and Slovak Chronicle on Charter 77 and its activists mentioned, for instance: a joint statement by the citizens of the countries participating in the intervention of 1968 (without informing who was the initiator of that statement) demanding the withdrawal of Soviet troops from the occupied countries and the trial of the initiators of the invasion of Czechoslovakia as well as the investigation of Soviet interventions in the Eastern Bloc, a demonstration on the occasion of the $70^{\text {th }}$ anniversary of the founding of Czechoslovakia on 28 October 1988 (organized by Charter 77, Czech Children, Democratic Initiative, the Independent Peace Group and the Society of Friends of the United States) and the intervention of the security services, a reduction in Ivan Polanskýs penalty on the occasion of the anniversary of the February Revolution of 1948, Symposium Czechoslovakia 88, held in Prague on November 11, 1988 and the arrest of Charter 77 activists and other organizations involved in its creation (Independent Peace Group, Democratic Initiative, Society of Friends of the United States and Jazz Section, The Chronicle also included the participation of British political scientist Timothy Garton Ash, ${ }^{126}$ former

125 A. M. P., Kronika czeska i stowacka, "Kultura" 1988, vol. 11, pp. 125-126.

126 Timothy Garton Ash (born on July 12, 1955 in London) - a graduate of the University of Oxford. British historian. In the 1980s he was a correspondent for "The Independent" and "The Spectator". Author of comments on the political and systemic 
Minister of Foreign Affairs of the Kingdom of the Netherlands - Max von der Stoel - and Secretary General of the International Helsinki Federation for Human Rights - Gerald Nagler ${ }^{127}$ ), the Symposium in Vienna, which was attended by P. Tigrid previously mentioned in this text and František Janouch, ${ }^{128}$ President of the Foundation Charter 77 in Stockholm, the establishment of the Czech Helsinki Committee headed by J. Hajek (former Minister of Foreign Affairs in 1968 involved in the activities of Charter 77) and the creation of the Social Defence Initiative on October 8, 1988 to help persecuted persons (building on the experience of the Polish Ombudsman and the Scandinavian Ombudsman), ${ }^{129}$ the participation of J. Hajek in the Symposium on Human Rights in Graz on December 5, 1988, the appointment of new Charter Advocates together with information on their résumés: Dana Němcová, ${ }^{130}$ Tomáš Hradílek ${ }^{131}$ and Alexandr (aka Saša)

transformations that took place in East-Central Europe at the end of the 1980s. Author of such works as: The Polish revolution: Solidarity (first Polish edition - 1987 in samizdat), The uses of adversity: Essays on the fate of Central Europe, London 1990, The magic lantern: The revolution of ' 89 witnessed in Warsaw, Budapest, Berlin, and Prague, London 1990 or The file: A personal history, Warszawa 1997.

127 Gerald Nagler (born on December 10, 1929 in Vienna). A co-founder of the International Helsinki Foundation for Human Rights and the Swedish Helsinki Committee for Human Rights. In the 1970s and 1980s, he was already active in the field of respect for human rights in communist countries.

128 František Janouch (born on September 22, 1931 in Lysá nad Labem). A graduate of the Faculty of Physics at the Leningrad University. He was awarded his doctorate at the Lomonosov Moscow State University. An activist of the Communist Party of Czechoslovakia, from which he was expelled in 1970. Then he emigrated to Denmark and then to Sweden, where he worked as a professor of Physics. In 1975 he was deprived of his Czechoslovak citizenship (regained in 1990). In Sweden he ran the Charter 77 Foundation.

129 A. M. P., Kronika czeska i stowacka, "Kultura” 1989, vol. 1-2, pp. 119-120.

130 Dana Němcová (born on January 14, 1934 in Most), studied Psychology and Philosophy at the Charles University in Prague. She worked as a clinical psychologist. She was the wife of the philosopher Jiři Němec - one of the initiators of Charter 77. After the Prague Spring, she organized concerts of The Plastic People of the Universe. Apart from her activity in Charter 77, she co-organized the Czech Helsinki Committee.

131 Tomáš Hradílek (born on April 28, 1945 in Lipník nad Bečvou). He studied Zootechnics at the University of Agriculture in Brno. An activist of the Communist Party of Czechoslovakia, from which he was expelled in 1969 for its criticism. He was associated 
Vondra, ${ }^{132}$ opposition and protests from literary circles (including the Polish and Hungarian PEN Club) and European governments and parliaments in connection with another arrest of V. Havel, subsequent issuing sentences for opposition activists such as: Jiri Tichý, ${ }^{133}$ Hana Marvanová, ${ }^{134}$ Tomás Dvořák and Ivan Martin Jirous ${ }^{135}$ as well as the cessation of the jamming of Radio Free Europe broadcasts from December 1988 by the Czechoslovak authorities. ${ }^{136}$

The Chronicle also presents statistics on Charter 77. During the 12 years of operation of Charter 77, signatures were submitted by 1,445 people (the number of signatures that reached the founders of Charter 77), 25 people withdrew their signatures, 47 died and 225 left Czechoslovakia (probably

with Charter 77 and co-founder of the Society of the Friends of the United States. In 1988, he co-founded the Movement for Civil Liberties. He was detained several times and sentenced for opposition activities. During the Velvet Revolution, he was active in the Civic Forum.

132 Alexandr (aka Saša) Vondra (born on August 17, 1961 in Prague) graduated in Geography at the Charles University in Prague. He was associated with the Polish-Czech-Slovak Solidarity. He was arrested for activities under Charter 77. He actively participated in the political life of Czechoslovakia (and then the Czech Republic) after 1989.

133 Jiri Tichý (born on April 2, 1946 in Prague), worked as a printer by profession. He was associated with Charter 77 and the Czechoslovak samizdat. After the death of Pavel Wonka, together with Ivan Jirous, he wrote a petition entitled “Tak dost!” (“Enough!”). He was convicted of opposition activities.

134 Hana Marvanová (born on November 26, 1962 in Rýmařov). She graduated in Law from the Charles University in Prague. In addition to her activities in Charter 77, she co-organized the Independent Association for Peace. She was arrested for participating in a demonstration on the occasion of the $20^{\text {th }}$ anniversary of the invasion of the Warsaw Pact troops. After 1989, she was active on the political scene in Czechoslovakia (and then in the Czech Republic).

135 Ivan Martin Jirous (born on September 23, 1944 in Humpolec - died on November 10, 2011 in Prague), a co-founder of the band The Plastic People of the Universe. He was also active as a poet and journalist, publishing in the Czechoslovak samizdat. In addition to Charter 77, he was associated with the Committee for the Defense of the Unjustly Persecuted (VONS). He was sentenced to imprisonment for opposition activities; see. M. Szczygieł, Láskov nebeskóv (chapter: Świrus niezłomy), Warszawa 2020, pp. 153-162.

136 A. M. P., Kronika czeska i stowacka, "Kultura" 1989, vol. 5, pp. 153-154. 
the actual number was 300-400 people). In turn, in 1988, the founding document was signed by 108 people and in the first three months of 1989 by 104 people. ${ }^{137}$

In the middle of 1989, The Chronicle reported on subsequent convicts. Vlasta Chramostová ${ }^{138}$ and Libuše Šilhánová were convicted of signing an open letter accusing the Czechoslovak government of lying in regard with the anniversary of Jan Palach's ${ }^{139}$ death. In turn, the spokesman for Charter 77, T. Hradílek, was convicted for a similar letter addressed to the Vienna CSCE. The Chronicle also announced the honoring of Pavol Čarnogurský140 and the other 30 Slovaks with the Cross of the National Army, the protest of Charter 77 against the construction of a hydroelectric power plant on the border with Hungary and the new document of Charter 77 entitled The tragedy of Jews in the Czechoslovak post-war reality, in which the question was posed as to whether anti-Semitism still existed in Czechoslovakia (this was evidenced by the closure of the Pinkas Synagogue in Prague in 1968, which was not reopened, as well as the Spanish Synagogue and the Maisel Synagogue in Prague). ${ }^{141}$

137 Idem, Kronika czeska i stowacka, "Kultura" 1989, vol. 7, p. 181.

138 Vlasta Chramostová (born on November 17, 1926 in Brno - died on October 6, 2019 in Brno), Czechoslovak and Czech actress. She was originally associated with the Communist Party of Czechoslovakia. In the 1970s she organized illegal theater performances in her apartment.

139 Jan Palach (born on August 11, 1948 in Prague - died on January 19, 1969), studied History and Political Economy at the Charles University in Prague. On January 16, 1969, he set himself on fire in front of the National Museum on Wenceslas Square in Prague in protest against the 1968 Warsaw Pact invasion and the passive attitude of Czechoslovak society.

140 Pavol Čarnogurský (born on January 22, 1908 in Malá Franková - died on December 27, 1992 in Bratislava). A teacher by profession. Before the Second World War, he was active in the Assembly of the Slovak Republic. He participated in the political life of the First Slovak Republic ruled by Fr. Jozef Tiso. He was imprisoned by the communist authorities. After the Second World War, he worked, among others, in the library of the Slovak University of Technology and as the administrator of the Červený Kameň castle. His son was Ján Čarnogurský - associated with the opposition in Czechoslovakia and a Slovak politician.

141 A. M. P., Kronika czeska i stowacka, "Kultura" 1989, vol. 7, pp. 181-182. 
Other initiatives mentioned in The Chronicle in 1989 concerned the petition Several sentences, whose spokespeople were V. Havel, S. Devátý, A. (aka Saša) Vondra, and Jiří Křižan. ${ }^{142}$ The petition called on the Czechoslovak government to "make real and consistent reforms", to release political prisoners, to introduce freedom of assembly, to stop the manipulation of the media, to legalize underground magazines and to allow the citizens to create civil movements. Information was also given about a letter from V. Havel to Polish Prime Minister Tadeusz Mazowiecki ${ }^{143}$ and Imre Pozsgay ${ }^{144}$ (one of the leaders of the Hungarian political system transformation) in which he asked for intercession in defense of Ján Čarnogurský145 and Miroslav Kusý146

142 Jiří Křižan (born on October 26, 1941 in Valašské Meziř́ííi - died on October 13, 2010 in Branki) Czech screenwriter (the author of the screenplay for the film Je treba zabit Sekala). In the 1980s, he was associated with the Movement for Civil Liberties (HOS). In January 1989, he co-edited the petition on the release of V. Havel and co-founded the Civic Forum.

143 Tadeusz Mazowiecki (born on April 18, 1927 in Płock - died on October 28, 2008 in Warsaw), one of the leading Polish politicians. In the era of communism, he was associated with Catholic circles. In the 1980s, one of the leading activists of Solidarity. As a result of the so-called June 1989 elections, on August 24, 1989, he took the position of the Prime Minister. He actively participated in the political life of Poland in the 1990s. In the years 1991-1995 he was a special envoy of the United Nations to Bosnia and Herzegovina.

144 Imre Pozsgay (born on November 26, 1933 in the village of Kóny - died on March 25, 2016 in Budapest). A Hungarian politician. In 1983-1994 he was a member of the Hungarian parliament. In 1976-1980 he was the Minister of Culture, in 1980-1982 the Minister of Education and in 1988-1990 the Minister of State. He participated in the changes in the Hungarian Socialist Workers' Party, which resulted in the establishment of the Social Democratic Party. He had a major influence on the political changes in Hungary in 1989.

145 Ján Čarnogurský (born on January 1, 1944 in Bratislava). A graduate of Law at the Charles University in Prague. He maintained contact with the Polish Club of Catholic Intelligentsia. He participated in the works of Charter 77. He was debarred for his opposition activities. He actively participated in the Czechoslovak and Slovak political scene after 1989 (from May 6, 1991 to June 24, 1992, he was the Prime Minister of Slovakia).

146 Miroslav Kusý (born on December 1, 1931 in Bratislava - died on February 13, 2019 in Bratislava). A graduate of the Faculty of Arts at the Charles University in Prague. He worked at the Comenius University in Prague. A member of the Communist Party 
members of the Slovak opposition (The Chronicle contains information about the intercession of T. Mazowiecki). ${ }^{147}$

\section{Conclusions}

Czechoslovak issues, which appeared in the pages of "Kultura" during the time of change associated with the so-called "Prague Spring", were discussed in subsequent years of communist rule in Poland and Czechoslovakia. It is worth adding that the form of presenting political issues took on a slightly different form than in 1968 or during the first years of Gustáv Husák's rule. At that time, the leading publicist very aptly and bluntly assessing the then situation in Czechoslovakia was Juliusz Mieroszewski, ${ }^{148}$ who presented his remarks either in thematic articles or in the English Chronicle. Unfortunately, Juliusz Mieroszewski died on June 21, 1976 in London - literally on the eve of the announcement of Charter 77 and disclosure of its signatories. His place in "Kultura" was mainly occupied by Czechoslovak publicists who successfully continued his work, informing Polish readers about the situation taking place in the CSSR. Thus, Paris "Kultura" became a place for not only the exchange of Polish independent and oppositional political thought, but also a free, unrestricted by a corset of censorship, analysis, as well as a place where members of the Czechoslovak opposition could present their texts.

of Slovakia, from which he was expelled in 1969. From 1977 he was associated with Charter 77. He was arrested and imprisoned for opposition activities. He was a co-founder of the Slovak Helsinki Committee.

147 A. M. P., Kronika czeska i stowacka, "Kultura" 1989, vol. 11, p. 101.

148 Juliusz Mieroszewski (born on February 3, 1906 in Krakow - died on June 21, 1975 in London). In the interwar period, he co-edited the Illustrated Daily Courier. During the Second World War, he served in the $2^{\text {nd }}$ Polish Corps. After the war, he stayed in exile. He was a close associate of Jerzy Giedroyc. In the years 1950-1972 he ran a permanent column in "Kultura", The English Chronicle. He was a supporter of reconciliation with Poland's eastern neighbors, at the expense of recognizing the inviolability of borders (ULB). He was an author of numerous political commentaries, including those relating to the Prague Spring. 
As I mentioned at the outset, "Kultura" issued by the Literary Institute was forbidden in Poland and people faced imprisonment for publishing it. For several decades, alongside Radio Free Europe, it shaped the attitudes of many Poles, also regarding the political situation in Czechoslovakia, and in the era of Charter 77, also through the opposition Czechoslovak publicists, among others.

Given J. Giedroyc's interests which revolved around eastern themes, namely Lithuania, Belarus and Ukraine, and the fact that the issue of our southern neighbor was not a central point in his eastern policy concept, the activity of V. Havel and Charter 77 was most particularly stressed against the background of opposition movements taking place in countries dependent on the USSR. One example may be the discussion of the opposition movement in Hungary. ${ }^{149}$

It is important that Charter 77 was not discussed as a nameless collective entity. Not only did V. Havel find his place in the pages of Parisian "Kultura" - undoubtedly as its leading figure, but also individual activists were mentioned. One example is The Czech and Slovak Chronicle, which presented the trials of activists and informed readers about the most important initiatives undertaken by the circle of Charter 77. This is so important because in the Polish consciousness only V. Havel appears as a member of the Czechoslovak opposition while the role of other spokesmen, Charter 77 or Slovak opposition activists is forgotten.

149 An example is the analysis of the Hungarian uprising of 1956 by a Hungarian historian - see G. Gömöri, Wegry po dwudziestu latach, "Kultura" 1977, vol. 1-2, pp. 140-144, or information on the signing of Charter 77 by 34 Hungarian intellectuals with a discussion on the attitude of the Hungarian communist authorities to this initiative and an outline of the Hungarian samizdat - idem, Dylematy "giętkiego reżymu", "Kultura" 1979, vol. 9, pp. 87-92 or presentation of the thesis contained in the Hungarian immigration press - J. D. J, Wegry i my, "Kultura" 1982, vol. 11, pp. 87-91. It needs to be explained that in the case of the comments on the situation in Hungary and the comparative analysis of the opposition in Czechoslovakia, I took into account the period from 1977 to 1990, that is from the moment of the creation of Charter 77 to the Velvet Revolution. In the case of Hungary, interesting materials should be mentioned, but concerning the events of 1956. I refer to the anthology of G. Lagzi Hungary and us. An anthology of Hungarian texts in the publications of the Literary Institute, Paryż-Kraków 2020, pp. 11-95, which presents texts and commentaries on the events of 1956. 
However, in the summary, I will allow myself to make a subjective reflection, namely that the Czechoslovak issue discussed since the mid-1970s has been lacking the comments and analyses presented by Juliusz Mieroszewski in connection with the Prague Spring and the intervention of the Warsaw Pact troops. Once again, the thesis that not all people can be replaced is confirmed. 